Lewis, M. G. (1967). Lancet, 2, 921.

Lukes, R. J. (1964). Fournal of the American Medical Association, 190,

914.
Martin, D. C., Rubini, M., and Rosen, V. J. (1965). fournal of the American Medical Association, 192, 752 .

Martin, L. S. J., Woodruff, M. W., Webster, J. H., and Pickren, J. W. (1965). Archives of Surgery, 90, 306.

Mathé, G., et al. (1968). Revue Française d'Études Cliniques et Biologiques, 13, 454 .

Medawar, P. B. (1961). Biographical Memoirs of the Fellows of the Royal Society, 7,95 .

Mikulska, Z. B., Smith, C., and Alexander, P. (1966). Fournal of the National Cancer Institute, 36, 29.

Miller, R. W. (1968). Fournal of the National Cancer Institute, 40, 1079.

Milner, J. E., Evans, C. A., and Weiser, R. S. (1964). Lancet, 2, 816.

Morton, D. L., Malmgren, R. A., Holmes, E. C., and Ketcham, A. S. (1968). Surgery, 64, 233

Moses, H. L., Glade, P. R., Kasel, J. A., Rosenthal, A. S., Hirshaut, Y., and Chessin, L. N. (1968). Proceedings of the National Academy of Sciences, 60,489 .

Murphy, J. B. (1926). Monographs of the Rockefeller Institute for Medical Research, No. 21.

Nadler, S. H., and Moore, G. E. (1965). Fournal of the American Medical Association, 191, 105.

Nadler, S. H., and Moore, G. E. (1966). Annals of Surgery, 164, 482.

Ngu, V. A. (1967). British Medical fournal, 1, 345.

Niederman, J. C., McCollum, R. W., Henle, G., and Henle, W. (1968). Fournal of the American Medical Association, 203, 205.

Old, L. J., Benacerraf, B., Clarke, D. A., Carswell, E. A., and Stockert, E. (1961). Cancer Research, 21, 1281.

Old, L. J., and Boyse, E. A. (1964). Annual Review of Medicine, 15, 167.

Old, L. J., and Boyse, E. A. (1965). Federation Proceedings, 24, 1009

Old, L. J., et al. (1966). Proceedings of the National Academy of Sciences, 56, 1699.

Old, L. J., Stockert, E., Boyse, E. A., and Geering, G. (1967). Proceedings of the Society for Experimental Biology and Medicine, 124, 63.
Page, A. R., Hansen, A. E., and Good, R. A. (1963). Blood, 21, 197

Peterson, R. D. A., Cooper, M. D., and Good, R. A. (1966). American fournal of Medicine, 41,342 .

Prehn, R. T., and Main, J. M. (1957). Fournal of the National Cancer Institute, 18, 769 .

Rosenthal, M. C., Pisciotta, A V., Komninos, Z. D., Goldenberg, H., and Dameshek, W. (1955). Blood, 10, 197.

Scanlon, E. F., Hawkins, R. A., Fox, W. W., and Smith, W. S. (1965). Cancer, 18, 782 .

Schwartz, R. S. (1968). Plenary session papers of the 12th Congress of the International Society of Hematology, New York, 1968.

Schwarzenberg, L., Mathé, G., Schneider, M., Amiel, J. L., Cattan, A., and Schlumberger, J. R. (1966). Lancet, 2, 365.

Smith, L. H., and Woodruff, M. F. A. (1968), Nature, 219, 197.

Smithers, D. W. (1962). Clinical Radiology, 13, 132.

Southam, C. M. (1965). European fournal of Cancer, 1, 173.

Southam, C. M., Moore, A. E., and Rhoads, C. P. (1957). Science, 125, 158.

Stewart, T. H. M. (1968). Canadian Medical Association fournal, 99, 342.

Talal, N., and Bunim, J. J. (1964). American fournal of Medicine, 36,

Tanigaki, N., Yagi, Y., Moore, G. E., and Pressman, D. (1967). Fournal

Wade, H. (1908). fournal of Pathology and Bacteriology, $12,384$.

Weiss, D. W., Bonhag, R. S., and DeOme, K. B. (1961). Nature, 190 889.

Whittle, R. J. M. (1957). British fournal of Radiology, 30, 7.

Wilson, R. E., Hager, E. B., Hampers, C. L., Corson, J. M., Merrill, J. P., and Murray, J. E. (1968). New England fournal of Medicine, 278, 479 .

Woglom, W. H. (1929). Cancer Review, 4, 129

Woodruff, M. F. A., and Boak, J. L. (1966). British fournal of Cancer, $20,345$.

Woodruff, M. F. A., and Nolan, B. (1963). Lancet, 2, 426.

Zur Hausen, H., Henle, W., Hummeler, K., Diehl, V., and Henle, G. (1967). Fournal of Virology, 1, 830.

\title{
Significance of the Changes in the Circulating Lymphoid Cells in Hodgkin's Disease
}

\author{
D. CROWTHER,* M.A., M.B., PH.D., M.R.C.P. ; G. HAMILTON FAIRLEY, $†$ M.A., D.M., F.R.C.P. \\ R. L. SEWELL, $\ddagger$ F.I.M.L.T.
}

\begin{abstract}
Summary: The lymphoid cell population in the peripheral blood in Hodgkin's disease differs from normal blood in three ways. Firstly, the number of large lymphoid cells actively synthesizing deoxyribonucleic acid is increased; secondly, the number of medium-sized lymphoid cells with intensely basophilic cytoplasm is increased; and, thirdly, occasional plasma cells are seen. These changes are related to the activity but not to the stage of the disease.

Similar changes are found under conditions of known antigenic challenge-that is, in infections-and after immunization, and in rheumatoid arthritis and systemic lupus erythematosus.
\end{abstract}

\section{Introduction}

In 1967 we published our preliminary data showing that there were morphological changes in the lymphoid cell population in the peripheral blood in Hodgkin's disease similar to those seen in infections following immunization and in two of the \footnotetext{
* Registrar, Department of Medicine, St. Bartholomew's Hospital,
London E.C.1.

† Consultant Physician, St. Bartholomew's Hospital, London E.C.1.

¥ Technician, St. Bartholomew’s Hospital, London E.C.1.
}

so-called autoimmune diseases, systemic lupus erythematosus and rheumatoid arthritis (Crowther et al., 1967).

Since then we have made further morphological and metabolic studies on the lymphoid cells in these diseases, and the purpose of this paper is to describe these results and to discuss in particular their significance in Hodgkin's disease.

\section{Patients}

Hodgkin's Disease.-Twenty-nine patients with completely untreated Hodgkin's disease were studied. The histological diagnosis was beyond doubt in every case. Eleven had localized disease without symptoms (stages I and IIA) and the remaining 18 had localized disease with symptoms or generalized disease (stages IIB to IV, Rye classification (Peters et al., 1966)). Bone-marrow biopsy and abdominal lymphangiography were used routinely in staging the patients.

Infections.-Eleven patients with viral and bacterial infections, including acute upper respiratory tract infections, acute pyelonephritis, pneumonia, tuberculosis, and staphylococcal empyema, were studied.

Autoimmune Diseases.-Six patients with active seropositive rheumatoid arthritis and three with systemic lupus erythematosus having L.E. cells and positive antinuclear factor tests were studied. 
Non-immunized Controls.-Fifty controls were studied. Of these, 10 were normal volunteers (medical staff) and the rest were patients suffering from diseases in which immune reactions are not a feature ; these included ischaemic heart disease, hypertension, peripheral vascular disease, duodenal ulceration, and iron-deficiency anaemia.

Immunized Volunteers.-Ten normal subjects (medical staff) were immunised either with Bordetella pertussis, T.A.B., or poliovirus and tetanus toxoid. The results recorded here are the changes in the lymphoid cell population six days after immunization, which is the time of maximum response of the lymphoid cell. The detailed studies on these patients have already been reported (Crowther et al., 1969).

Antigens.-The following antigens were used: (1) Bordetella pertussis (Burroughs Wellcome), $1 \mathrm{ml}$. intramuscularly containing $4 \times 10^{10}$ killed organisms. (2) T.A.B. Vaccine (Burroughs Wellcome), $0.5 \mathrm{ml}$. intramuscularly containing $5 \times 10^{8}$ killed Salmonella typhi and $2.5 \times 10^{8} \mathrm{~S}$. paratyphi $\mathrm{A}$ and $\mathrm{B}$. (3) Poliovaccine (Burroughs Wellcome), $0.5 \mathrm{ml}$. intramuscularly containing killed poliovirus types 1, 2, and 3. (4) Tetanus vaccine B.P. (Burroughs Wellcome), $0.5 \mathrm{ml}$. intramuscularly, (5) Delayed hypersensitivity reagents $(0 \cdot 1 \mathrm{ml}$. intradermally); diluted Varidase preparation (streptokinase $10 \mathrm{u} . / 0 \cdot 1 \mathrm{ml}$.) and streptodornase $(2.5 \mathrm{u} . / 0 \cdot 1 \mathrm{ml}$.) and tuberculin as purified protein derivative (10 u. $/ 0 \cdot 1 \mathrm{ml}$.).

\section{Laboratory Methods}

Separation of Peripheral Blood Lymphocytes.-The method used was a slightly modified version of that of Coulson and Chalmers (1967). Defibrinated blood was mixed with finely divided carbonyl iron powder (type SF, Fine Dyestuffs \& Chemicals, Ltd.) in the proportions $10 \mathrm{ml}$. to $100 \mathrm{mg}$. in $25-\mathrm{ml}$. Universal glass bottles for 30 minutes at $37^{\circ} \mathrm{C}$. To every $10 \mathrm{ml}$. of blood, $3 \mathrm{ml}$. of $1 \%$ methyl cellulose (Methocel) in 0.15 molar phosphate buffered $0.9 \% \mathrm{NaCl}$ solution $p \mathrm{H} 7.2$ was added. Bubbles were removed by carefully pipetting the mixture into another Universal bottle and allowing it to stand for 30 minutes at $37^{\circ} \mathrm{C}$. During this procedure the granulocytes and monocytes which had taken up the iron settled out with the red cells. The supernatant contained over $98 \%$ lymphoid cells. Smears of the lymphoid cells were prepared, air-dried, and stained with Leishman's stain. The relative numbers of the different types of lymphoid cells present were counted by two independent observers, the results being averaged. At least 1,000 cells were counted on each slide by each observer ; 2,000 cells were counted when the number of large lymphoid cells was less than $1 \%$. All slides were counted without the observers knowing to which experiment these belonged.

Electron Microscopy.-The cells were fixed in $1 \%$ glutaraldehyde in $0.15 \mathrm{M}$ phosphate buffer $p \mathrm{H} 7.2$ for two hours, followed by $1 \%$ osmium tetroxide in phosphate buffer at $5^{\circ} \mathrm{C}$. for 30 minutes. After staining with Karnofsky's lead stain for one hour the cells were dehydrated in ethyl alcohol and embedded in araldite. Thin sections were cut with a Huxley microtome, mounted on uncoated copper grids, and examined with a Philips EM. 300 electron microscope.

Scintillation Counting after Labelling with Tritiated Thymidine and Uridine.-The lymphocyte preparations were diluted with tissue culture medium 199 (Glaxo) to a final concentration of approximately 1 million lymphoid cells per ml. and divided into 4-ml. portions. The uptake of tritiated thymidine and tritiated uridine by these cells was estimated as follows: The tritiated precursor $(5 \mathrm{Ci} / \mathrm{mM})$ was added to each $4-\mathrm{ml}$. cell suspension at a concentration of $1.25 \mu \mathrm{Ci} / \mathrm{ml}$. and the mixture incubated for 30 minutes at $37^{\circ} \mathrm{C}$. After cooling in an icebath for five minutes the preparations were centrifuged and the supernatants discarded. The deposited cells were extracted twice with $2 \mathrm{ml}$. of ice-cold $5 \%$ trichloracetic acid, followed by two extractions at room temperature with $2 \mathrm{ml}$. of absolute alcohol. The final pellet was dissolved in $0.5 \mathrm{ml}$. of $\mathrm{N}$. KOH and its contents of tritium estimated in a Beckman LS.200 liquid scintillation counter with a B.B.O.T. (Ciba Limited) containing scintillation fluid. This consisted of naphthalene 80 g., B.B.O.T. 8 g., toluene $600 \mathrm{ml}$., and 2-methoxyethanol $400 \mathrm{ml}$. The amount of quenching was assessed for each sample by means of an external standard. The results were calculated as counts per minute per million cells.

Autoradiography. - The lymphocyte preparation was incubated for 30 minutes with the tritiated precursor, $1.25 \mu \mathrm{Ci}$ of tritium per $\mathrm{ml}$. being used. The tritiated precursors used were thymidine $-6-\mathrm{T}(5 \mathrm{Ci} / \mathrm{mM})$, uridine $-5-\mathrm{T}(5 \mathrm{Ci} / \mathrm{mM})$, and DL-leucine -4, 5-T (18Ci/mM) (Radio Chemical Centre). Smears were made and fixed for 10 minutes in methyl alcohol. Autoradiographs were prepared with Ilford K5 nuclear research emulsion. After exposure of the autoradiographs of thymidineand uridine-labelled cells for seven days, and the autoradiographs of leucine-labelled cells for 14 days, the slides were developed, fixed, and stained with Leishman's stain. In each preparation 10,000-15,000 cells were inspected. All cells with over 10 grains were counted as positive.

\section{Results}

\section{Total Lymphocyte Counts in Peripheral Blood}

Fig. 1 shows the total lymphocyte counts in both treated and untreated patients with Hodgkin's disease compared with normal controls. There is a clear difference between the controls and the group of treated patients, but the majority of untreated patients had total lymphocyte counts within the normal range-a result similar to that recorded by Brown et al. (1967).

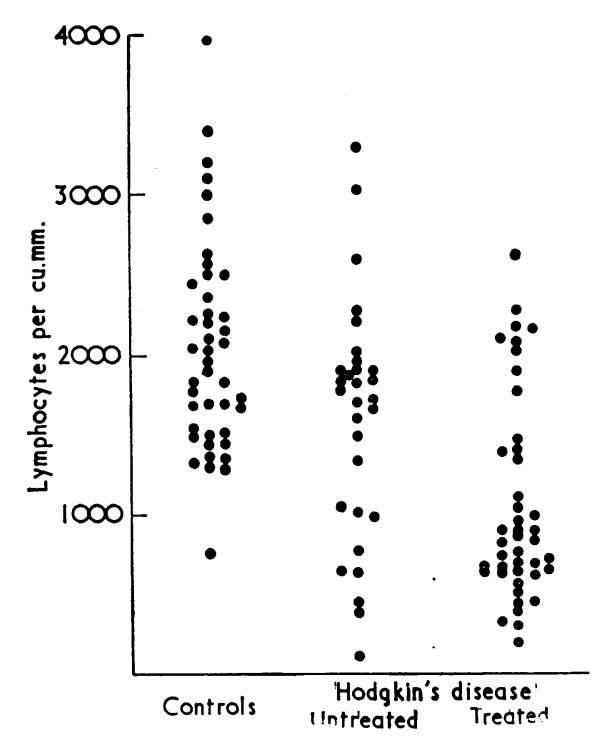

FIG. 1.-Total lymphocyte counts in peripheral blood in patients with untreated Hodgkin's disease compared with treated patients and
controls.

\section{Morphology of Lymphoid Cells in Peripheral Blood}

Changes in the lymphoid cell population of the blood were noticed in 21 out of 27 patients with untreated Hodgkin's disease (Fig. 2). Three types of cell were found in increased numbers: 
(1) An increase in numbers of large lymphoid cells, up to $4 \%$ of their total, was observed. This represented an increase in absolute numbers of these cells in the blood. These cells were 15-23 $\mu$ in diameter, with prominent nucleoli, deeply basophilic cytoplasm, and a well-developed Golgi zone. Electron microscopy showed that the high cytoplasmic ribonucleic acid content was accommodated in polyribosomes. There was very little endoplasmic reticulum in

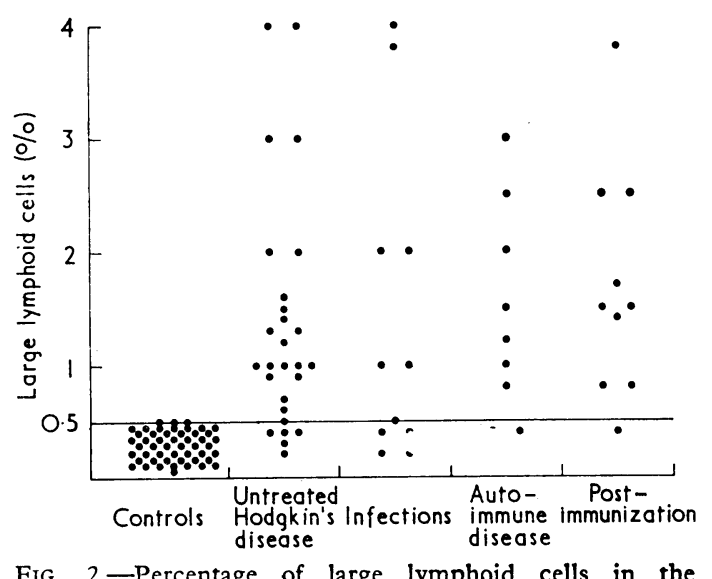

lymphocyte preparations in peripheral blood.

these cells (Fig. 3a). The cytoplasm did not give the periodicacid-Schiff reaction. A small number of large lymphoid cells of the blast type may be found in normal subjects, but the numbers never exceeded $0.5 \%$ of the lymphoid cells present in the 50 controls studied.
(2) The most prominent change in the lymphoid cell population was an increase in numbers of medium-sized hyperbasophilic lymphoid cells-10-20\% of the cells were of this type in reactive preparations. Electron microscopy showed that considerable numbers of these cells had sufficient endoplasmic reticulum for them to be included in the plasma cell series (Fig. 3b).

(3) An occasional mature plasma cell was seen with well-developed endoplasmic reticulum.

Similar changes were also found after immunization, in viral and bacterial infections, and in the autoimmune diseases (Figs. 2 and 4 ).

\section{Metabolic Studies}

Fig. 5 shows that the uptake of tritiated thymidine parallels the increase in the percentage of large lymphoid cells and the labelling index (Fig. 6). Autoradiography confirmed that nearly all the cells incorporating tritiated thymidine were large lymphoid cells. About $30 \%$ of these cells were in the deoxyribonucleic acid synthetic phase of cell growth. Mitotic figures were present in most reactive preparations, but only one mitotic figure was seen in 50 control preparations, though several thousand cells were scanned in each case. Both the large and medium-sized lymphoid cells were labelled with tritiated uridine, and similar results were obtained with tritiated leucine. Similar patterns of labelling with all three tritiated precursors were found in lymphoid cell populations from patients with autoimmune disease and infection and in subjects after

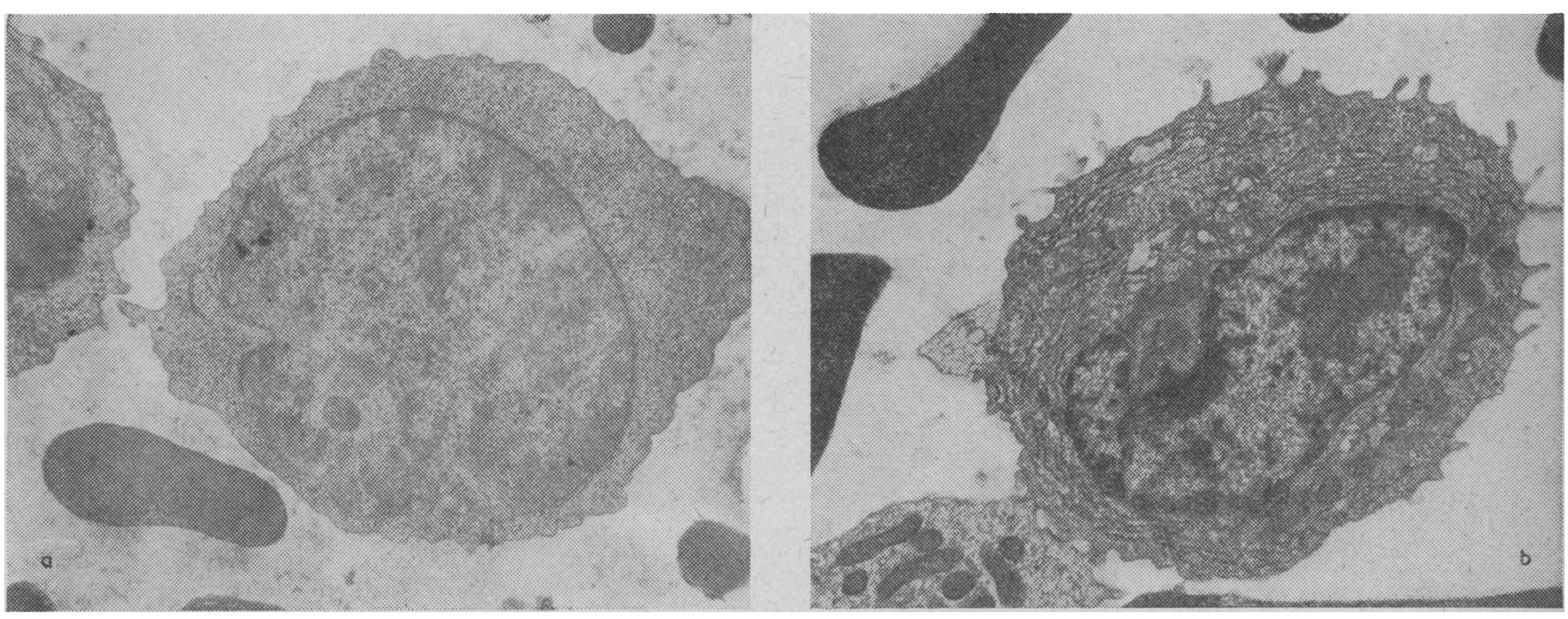

FIG. 3.-Flectron photomicrographs of cells in the lymphocyte preparations from the periphcral blood in Hodgkin's disease. (a) Large lymphoid cells with polyribosomes. (b) Medium-sized hyperbasophilic lymphoid cell with loosely woven endoplasmic reticulum that is an immature plasma cell.

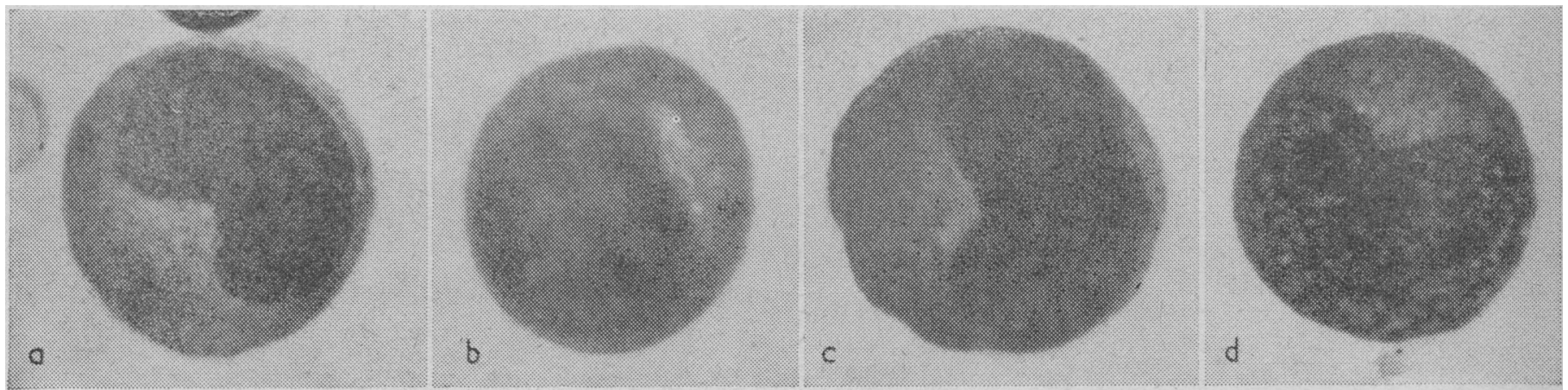

FIG. 4.-Large lymphoid cells in the peripheral blood. (a) Hodgkin's disease. (b) Patient with acute upper respiratory tract infection. (c) Autoimmune disease (systemic lupus erythematosus). (d) After immunization with T.A.B. in a normal volunteer. 
immunization. Few lymphoid cells were found in controls labelled with tritiated uridine or leucine with our technique.

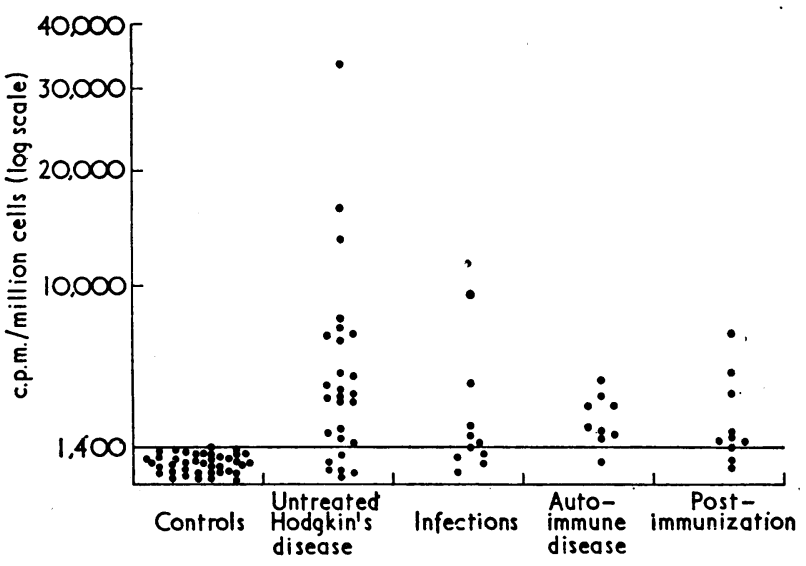

Frg. 5.-Uptake of tritiated thymidine by blood lymphoid cells.

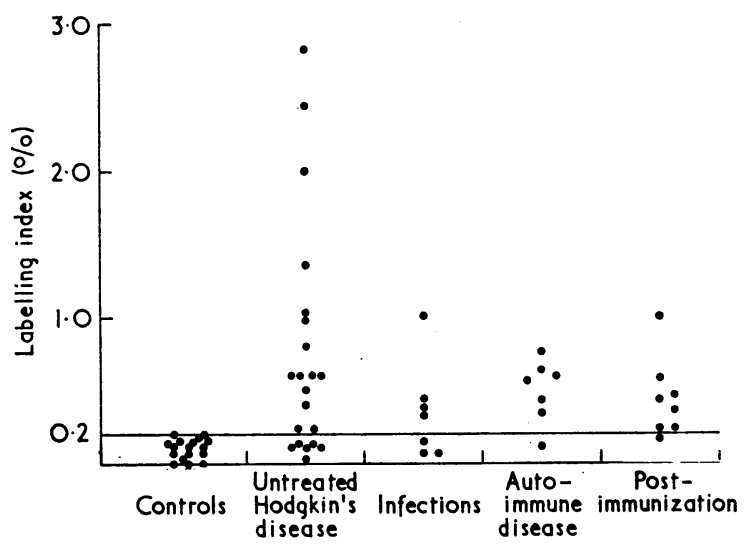

FIG. 6.-Percentage labelling of peripheral blood lymphoid cells with tritiated thymidine.

\section{Above Findings in Relation to Course of Disease}

Fig. 7 shows that there was no correlation between the stage of the disease and the percentage of large lymphoid cells in the peripheral blood. There was, however, a definite correlation between the activity of the disease and the percentage of large lymphoid cells, as shown in Fig. 8. Out of 13 patients

Fig. 7.-Large lymphoid cells in patients with local and generalized untreated Hodggeneralized untreated Hodg-
kin's disease, showing no difference between the two groups.

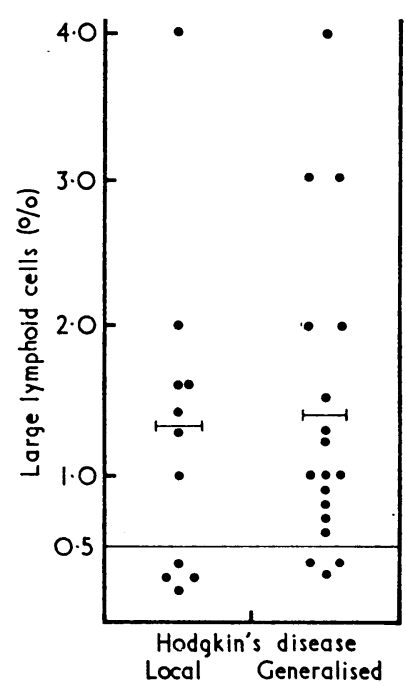

treated with radiotherapy, 10 responded completely so that all signs of disease disappeared, and in these patients the percentage of large lymphoid cells returned to within the normal range one month after treatment or was normal throughout. In the three patients who failed to respond to radiotherapy there was a rise in the percentage of large lymphoid cells.

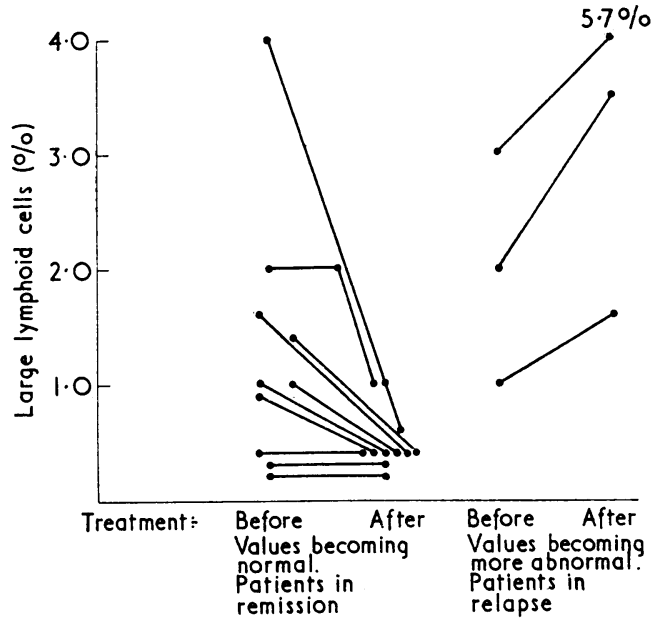

FIG. 8.-Changes in percentage of large lymphoid cells in Hodgkin's disease after treatment with radiotherapy. Blood was taken before and one month after treatment. In the first group the patients all responded satisfactorily to treatment and the lymphoid cells returned to more normal values. In the group three patients failed to respond and the percentage of lymphoid cells increased.

There was no correlation between the delayed hypersensitivity response to tuberculin and streptokinase/dornase or between the degree of lymphocytic infiltration in the biopsy specimen and the numbers of large lymphoid cells in the blood.

Three patients whose blood showed abnormal lymphoid cell populations which returned to normal after radiotherapy were subsequently immunized with T.A.B., and each responded by producing changes in the lymphoid cells indistinguishable from those seen when their disease was active. This was, of course, only a transient change directly related to antigenic challenge. Another three patients showed the identical phenomenon when they developed a herpes zoster infection during a period of complete remission.

\section{Discussion}

Klima (1952) described reactive hyperbasophilic cells in the blood of patients with Hodgkin's disease ; however, no quantitation or metabolic studies were done. Kuper and Bignall (1964) studied seven patients with Hodgkin's disease and found increased numbers of cells in the blood capable of taking up tritiated thymidine in three, though using their technique they were unable to identify the cells. It was not stated whether these patients were treated or not. It is unlikely that the hyperbasophilic cells are neoplastic, since malignant cells are rarely present in blood, and are usually found only in patients with generalized disease (Bouroncle, 1966). If the large lymphoid cells are malignant they are not the characteristic malignant cells of Hodgkin's disease.

One explanation for the presence of reactive lymphoid cells in the blood is that these cells are the result of disruption of the normal architecture of the lymph node leading to the appearance of cells normally confined to the node. A comparable situation would be the leuco-erythroblastic anaemia seen when the architecture of the bone marrow is disrupted. We have, however, not seen these changes in the peripheral blood in patients with secondary carcinoma infiltrating the lymph nodes.

The presence of cells of the plasma cell series and the similarity to the lymphoid cell population of the blood in subjects after immunization suggest that an immunological 
reaction is in progress, but it is 'not clear against what antigen it is directed. It is just possible that the disease could result from some form of chronic immunological reaction (a situation analogous to the NZB mice with autoimmune haemolytic anaemia and to experimental animals with chronic graft-versushost disease, both of which have an increased incidence of tumours of the reticuloendothelial system (East and Prosser, 1967 ; Schwartz, 1968), but there is little evidence to support such a view.

The changes in Hodgkin's disease could represent a reaction against an undiscovered associated infection. Such an explanation is impossible to refute, but most of the patients studied had no fever and no clinical or laboratory changes indicating infection. Nevertheless, a continuing search for viral infections in this disease may well prove rewarding, particularly in view of the recent work of Epstein et al. (1964), Klein et al. (1968), and Henle et al. $(1966,1968)$ showing a herpesvirus infection to be an invariable accompaniment of Burkitt's lymphoma and infectious mononucleosis. Patients with Hodgkin's disease are known to be particularly prone to certain viral, bacterial, fungal, and parasitic infections (Aisenberg, 1966).

Immunological reactions have now been found in a number of human malignant diseases, but it is not known whether the presence of such a reaction is merely a consequence of tumour degeneration rather than a factor in host resistance. The most interesting explanation is that the reactive lymphoid cells are present in response to the putative tumour-specific antigen, and hence the disease, but the possibility remains that they represent a reaction to tumour products.
We wish to thank Sir Ronald Bodley Scott for permission to study patients under his care, Dr. A. Stansfield, who confirmed the diagnosis of Hodgkin's disease in every case, Mr. M. S. C. Birbeck for his assistance with the electron microscope, and the Wellcome Foundation Limited and the B.E.C.C. for generous financial support.

\section{REFERENCES}

Aisenberg, A. C. (1966). Cancer Research, 26, 1152.

Bouroncle, B. A. (1966). Blood, 27, 544.

Brown, R. S., Haynes, H. A., Foley, H. T., Godwin, H. A., Berard, C. W., and Carbone, P. P. (1967). Annals of Internal Medicine, 67, 291.

Coulson, A. S., and Chalmers, D. G. (1967). Immunology, 12, 417.

Crowther, D., Fairley, G. H., and Sewill, R. L. (1967). Naiure, 215, 1086 .

Crowther, D., Fairley, G. H., and Scwsll, R. L. (1969). Fournal of Experimental Medicine, 129, 849.

East, J., and Prosser, P. R. Proceedings of the Royal Society of Medicine, $60,823$.

Epstein, M. A., Achong, B. G., and Barr, Y. M. (1964). Lancet, 1, 702.

Henle, W., Hummeler, K., and Henle, G. (1966). fournal of Bacterio$\log y, 92,269$.

Henle, G., Henle, W., and Diehl, V. (1968). Proceedings of the National Academy of Sciences, 59, 94

Klein, G., Pearson, G., Henle, G., Henle, W., Diehl, V., and Niederman, J. C. (1968). Fournal of Experimental Medicine, 128, 1021.

Klima, R. (1952). Wiener Zeitschrift für innere Medizin und ihre Grenzgebiete, 33, 125

Kuper, S. W. A., and Bignall, J. R. (1964). Lancet, 1, 1412.

Peters, M. V., Alison, R. E., and Bush, R. S. (1966). Cancer, 19, 308.

Schwartz, R. S. (1968). Plcnary Session Papers of the 12th Congress of the International Society of Hematology, New York, 1968.

\title{
Prevention of Prolonged Labour
}

\author{
KIERAN O’DRISCOLL,* M.A.O., F.R.C.P.I., F.R.C.o.G. ; REGINALD J. A. JACKSON, $\dagger$ M.D., M.A.o., M.R.C.o.G. \\ JOHN T. GALLAGHER, $\dagger$ M.A.O., M.R.C.o.G.
}

Summary : A prospective study of 1,000 consecutive primigravid deliveries has shown that active management in labour can ensure that every woman is delivered within 24 hours. Emphasis is laid on the importance of a correct initial diagnosis of labour based on objective criteria. Amniotomy followed by oxytocin infusion is advocated to simulate the progress of normal labour unless this is evident from an early stage.

Oxytocin, the dose of which is limited only by foetal distress, cannot be used effectively unless three popular fallacies are rejected. Firstly, that prolonged labour is often an expression of cephalo-pelvic disproportion; secondly, that oxytocin may rupture the primigravid uterus; and, thirdly, that there is a valid therapeutic distinction between hypotonic and hypertonic uterine action.

Stimulation, properly supervised, is safe to mother and child, it eliminates the problem of occipitoposterior position, results in a sharp decline in forceps delivery, and obviates the need for massive analgesia.

* Master, National Maternity Hospital, Dublin 2.

T Assistant Master, National Maternity Hospital, Dublin 2.

\section{Introduction}

Prolonged labour presents a picture of mental anguish and physical morbidity which often leads to surgical intervention and may produce a permanent revulsion to childbirth, expressed by the mother as voluntary infertility; it constitutes a danger to the survival and subsequent neurological development of the infant (Jeffcoate et al., 1952 ; Lancet, 1963). The harrowing experience is shared by relatives, and by doctors and nurses to the extent that few complications so tarnish the image of obstetrics.

There have been many publications on the subject which have been concerned mainly with aetiology, complications, and treatment (Hawkins and Nixon, 1957 ; Garrett, 1960 ; Barr, 1964). When prevention has been considered the value of stimulation has been presented as controversial or the application has been restricted by excessive caution (Garland, 1961; Schulman, 1966). Because no course of management which is not qualified by serious limitations has been described, it is not surprising that prolonged labour continues to be a problem. The purpose of this paper is to show that prolonged labour can be prevented by effective stimulation. In the process it is emphasized that some of the conventions of delivery ward parctice must be abandoned. 